January 1998

\title{
The Japanese Big Bang as a Unilateral Action
}

\author{
Koichi Hamada*
}

\begin{abstract}
Japan followed the British example of the "Big Bang" in April 1998. This move towards "Big Bang" is a unilateral action without requiring any conditions for the policy measures of other countries. This move has many economic grounds. The Japanese financial system has had incentive problems. Financial agents were looking at, or watching, the signals of policy makers and supervising administrative authorities rather than watching the signals of the markets. This created prolonged financial difficulties during the 1990s. The "Big Bang" is an attempt to liberalize the Japanese market towards the external world and, thereby, deregulate the internal financial market. Needless to say, political resistance against the process exists by various interest groups. If the "Big Bang" question overcomes the resistance, however, it may work as an effective means of modernizing and revitalizing the Japanese financial system by restoring proper incentive mechanisms.
\end{abstract}

\footnotetext{
* I owe much to the insightful comments by Jagdish Bhagwati, David Weinstein and Lawrence White. I also thank Fumiko Takeda and Shiro Yabushita for their helpful discussions and Carolyn M. Beaudin for her editorial contributions.
} 


\section{Introduction}

For more than a quarter of a century, Japan has been the greatest capital exporter in the world thanks to her large surplus in savings. In quantity, she has been a great financial nation. In quality, however, her financial market has been far from efficient. In spite of the enormous scale of financial sectors, the efficiency in financial intermediation in Japan was dwarfed by government regulations that protected the interests of financial industries at the expense of individual users. ${ }^{1}$ These weaknesses of Japan's financial sectors were brought to the world's attention by the recent financial turmoil that involved banking, insurance and securities sectors.

Japan, of course, has tried to rebound from this crisis by taking a unilateral action. She considered the revitalization of the British financial market as a compelling example. On November 11, 1996, Prime Minister Ryutaro Hashimoto of Japan announced an ambitious plan for a "Big Bang” in Japan's financial market (Imai 1997, Nikkei, 1997). ${ }^{2}$

Since the plan involves not only the liberalization of the security industry but also the banking and the insurance industries, Japan's "Big Bang" is expected to be, if it is realized as was conceived, even more spectacular than the original "Big Bang" in the United Kingdom in 1986 (Imai, 1997). In England, the main emphasis in deregulation was in the security market. In Japan the plan is expected to cover all the financial sectors, including banking, securities and insurance.

Japan's "Big Bang" is the reaction of Japan's government to the declining position of Tokyo's financial market in the world (Imai, 1997). There is consensus that, due to the suppression of an effective incentive mechanism by the monetary authorities, Japan's financial market lost its relative importance in the world. The "Big Bang" plan is a "last resort" rescue plan for Japan's financial market.

Japan’s “Big Bang” attempts to deregulate Japan's financial market by opening the

\footnotetext{
${ }^{1}$ According to the 61st Report of the Bank for International Settlements (BIS), Japanese banks accounted for about $35 \%$ of the total assets owned by the BIS member banks and about 34\% of their total liabilities at the end of 1990. Tokyo, along with its offshore banking facilities, has become one of the three largest stock and currency markets.

${ }^{2}$ He directly addressed his plan to the Finance Minister and the Justice Minister of his cabinet. This is interpreted as an indication that the Prime Minister has seriously considered the legislative implementation of the plan (Imai, 1997).
} 
borders of its financial market. "Free," "Fair" and "Global" are the key words. Politicians choose these generic words not because they are well defined, but because they appeal to the emotions of people. But the underlying logic seems to be that the "Globalization" of the market, when implemented, will create a "Free" and "Fair" market in Japan. An internationally open market obliges policymakers to terminate domestic regulation, because an open market with domestic regulation will either export financial activities abroad or give foreign financial institutions the lion's share of the domestic market. In other words, if regulation in the domestic market is tight, funds will flow abroad. If foreign firms can operate in the domestic market, they can exploit arbitrage opportunities due to the existence of regulation. While the openness necessitates deregulation, deregulation generally promotes openness but does not absolutely require the openness of an economy as a prerequisite. Thus, the best way to deregulate is first to open the market to the world.

The scheduled actions by Japan are unilateral. Nothing is stated about reciprocity with respect to other countries' policies. Hardly any new conditions are imposed as prerequisites on foreign firms as requirements for participating in Japan's financial market. In this sense Japan's "Big Bang" is a typical example of unilateral liberalization. An analysis of the economic reasons that led to Japan's failure, as well as of the endogenous political factors that initiated the move towards liberalization, is the central task of the paper.

We begin in Section II by describing the historical development of Japan's financial market since the inter-war period and emphasizing the strengthening authority of the Ministry of Finance (MOF) in the financial sector. In Section III we describe the resulting process of the boom and its collapse since the late 1980s, which was a result of erratic macroeconomic policies.

A large quantity of savings enabled Japan to dominate the world capital market, but the quality of financial services in Japan lagged behind the industrialized countries due to excessive regulation. This created the need for opening the financial market as a unilateral action. In Section IV we point out the deficiency of the incentive mechanism that arose from excessive regulation in the financial market. We continue, in Section V, by studying the economics of the unilateral action in general terms, and, finally, in Section VI, examine the incentive structure of the political economy of unilateral policy actions and reforms. 


\section{Japan's Traditional Financial System}

In order to understand the nature of Japan's financial system, a historical account is useful. In fact, the history of Japan's banking is the history of strengthening control by the Ministry of Finance. $^{3}$

The history of Japan abounds with examples of borrowed foreign institutions and technologies. At first, "foreign" implied China, from which Japan imported language, religion, and legal as well as bureaucratic systems as early as the 7th century. "Japanese spirit and Chinese talent" was the motto. After the Meiji Restoration, China was replaced by Western industrialized countries as the "foreign" sources. The Japanese government sent delegates to find where the best institution existed for their purpose. The army is from the French system, the Navy is from the British Royal Navy, and so forth (Morishima, 1984). Western talent, technologies and institutions were supposed to be tamed for domestic use by the Japanese spirit.

The monetary system was not an exception. The Central Bank, the Bank of Japan (BOJ), modeled after the Belgian Central Bank, was chartered in 1882. The Bank of England was considered at that time to be the most prestigious in the world, but the Belgian Central Bank became the example emulated because it allowed more influence by the government. The National Banking System was introduced, but in this case the introduction caused the emergence of too many "national banks", excessive creation of money and inflation.

World War I (1914-18) brought Japan a period of prosperity through the export demand that was followed by a stock market boom. The boom was interrupted by a stock market crash in March, 1920. On March 15th, the Tokyo Stock Exchange prices lost their values as if "autumn leaves were driven by wind (Tokyo Stock Exchange, 1928)." The Tokyo Stock Exchange closed its operation for the two following days. On April $7^{\text {th }}$, Masuda Broker Bank --- a bank that financed stock brokers --- suspended its payments and, consequently, the Tokyo as well as the Osaka Exchange had to cancel trading. Seven commercial banks (including Konoike and Sumitomo) agreed to finance rescue lending to the Masuda Broker Bank. Each stock market, when reopened on April 13th, continued to decline and triggered a decline in commodity markets, notably those of cotton and silk. Many small banks were under attack by withdrawals of savings

\footnotetext{
${ }^{3}$ The following are excerpts from Hamada.
} 
and suspended business. In May a substantial bank, Shichiju-yon (Seventy-Fourth) Ginko went bankrupt. The stock price index was not yet calculated when this occurred, but the stock in the Tokyo Stock Exchange is estimated to have declined almost $50 \%$ between the beginning of March and the middle of April. From April to July, 169 bank offices were under bank runs, and 21 banks had to suspend business. Two hundred and thirty-three firms went bankrupt during the period from May to the middle of July.

To cope with the financial crisis and the collapse of the credit system, the BOJ extended loans amounting to 240 million yen (the exchange rate at that time was about $(Y 2=\$ 1)$ in order to provide reserves and sufficient liquidity for troubled banks as well as for brokers and dealers in the stock and the commodity markets. Most of them were paid back to the BOJ in two years. These loans signaled to the public, the role of the central bank as the lender of last resort, and they were in fact repeated in the subsequent financial squeeze, on a smaller scale, in 1922.

On September 1st, 1923, the eastern part of Japan was hit by a devastating earthquake that registered about 7.9-8.2 on the Richter scale. Three quarters of the residents in Tokyo and 95\% of those in Yokohama suffered from the earthquake and resulting fires. More than 140,000 people died. The total physical damage caused by the earthquake was estimated to be 5.5 billion yen, (equivalent to 2.2 billion dollars), which was $42 \%$ of the GNP of the year. ${ }^{4}$ Banks and financial institutions were seriously affected.

The government tried to provide necessities to the devastated area. It issued the Ordinance of Moratorium that allowed a thirty-day postponement of debt payments, except for wage payments, salaries and deposits under a certain amount. It was also stipulated that the BOJ would rediscount "earthquake bills" until the end of March 1924. Earthquake bills were defined as commercial bills that were either bank bills due for payments in the affected areas or bills issued by firms operating in the affected areas. The Moratorium was discontinued after thirty days, but the large accumulation of these earthquake bills set the stage for the financial crisis of 1927.

In 1926, the ailing Taisho Emperor met his demise. The new name of the era was chosen as Showa" (jau-he) -- from the Chinese classic The Documents of Yao -- meaning that the emperor as well as the people cooperate for world peace (Goto, 1990). On the contrary, the first

\footnotetext{
${ }^{4}$ We rely on the GNP estimates by Ohkawa and by Yamada.
} 
half of the Showa era turned out to be a history of economic depression and Japan's militaristic aggression in Asia.

The main drama of the 1927 (the second year of Showa) financial crisis started on March 14th when, in the Diet that was discussing the process of redeeming the earthquake bills, the Finance Minister Naoharu Kataoka said, "Today at noon, Watanabe Bank in Tokyo finally failed to meet the demand for withdrawals." The fact was, it is now told, that the Watanabe bank went into financial difficulties in the morning, but through concerted efforts it managed to deal with customers in the afternoon. However, these words by the Finance Minister in the Diet created a reaction of distrust and fright among depositors. Many banks that were rumored to be unsound faced bank runs for withdrawal by depositors.

At that time, the Taiwan bank was considered most insecure in terms of delinquent debts in its operation with Suzuki \& Company. Suzuki \& Company operated aggressively in Asian Trade and had a monopoly on camphor trade with Taiwan. The company also held a large amount of earthquake bills amounting to 430 million yen, $26 \%$ of which were financed by loans from the Taiwan bank. Taiwan Bank as well as Ohmi Bank, which was important in the Western cloth trade, suspended their business. The chain reaction of rumors created a panic situation in Japan, and on April 23rd and 24th all the banks were closed by their, allegedly voluntary, coordinated action. To order a moratorium, a special imperial ordinance would have been needed. This would have caused traumatic panic. That was why voluntary actions were first requested from the banks. After these closing days, a moratorium of three weeks was announced, and the BOJ started supplying money by lending to the banks that were dealing with unprecedented bank runs. Thirty-two banks suspended operation in April and May and forty-five banks followed suit during 1927. The BOJ acted as the lender of last resort. The BOJ had to print bank notes so rapidly that they issued 200 yen bills with white backs --- i.e., without any printing on the other side. Incidentally, the degree of the stock market crash during that year was about $20 \%$ and milder than that in 1920 .

In the meantime, Japan was contemplating its return to the gold standard that she had left after the outbreak of World War I. The new Finance Minister, Junnosuke Inoue, strongly believed that returning to the gold standard was a necessary step in making Japan a respectable 
member of the club of industrialized nations. He staged in 1929, the return to the gold standard with a yen value substantially appreciated by about $18 \%$. The Japanese economy therefore went into a severe depression. Prices went down precipitously. Output declined only around 10\%, but the consumer price and the investment goods price declined $27 \%$ and $33 \%$ respectively during 1926 to 1931 . The rural sector was severely depressed by the decline of the relative price of agricultural to industrialized products. It was certainly one of the factors that promoted the Fascist movements that led Japan into the reckless World War II.

The rescue lendings by the BOJ amounted to 679 million yen, this is almost $5 \%$ of the national income of 1927. It was not until 1952 --- twenty-five years later --- that banks could repay their liability from this emergency measure to the BOJ. This alone demonstrates the magnitude and the gravity of the Showa financial crisis.

Even before the outbreak of the financial crises of 1927, the Ministry of Finance (MOF) had been planning to legislate a bank regulation law. Coincidentally, it was exactly in the middle of the financial crisis, March 30, 1927, that the Diet passed the Banking Act.

The MOF regulations started to reorganize the banks by merger. They proposed the principle of one bank for each prefecture (at that time Japan had 47 prefectures). In fact, the number of banks was reduced from 1,283 to 61 in 1945.

The MOF increased its control with the enactment of the Bank Law in 1927. The MOF now controlled entry, jurisdiction of business, deposit interest rates, and the opening of new branch offices. Through the assistance of the BOJ as well as the MOF, even loan interest rates and various fees were fixed by the associations of banks and other financial institutions. In return, the MOF promised the protection of financial institutions, the policy being called "Banking Administration by Convoys." Thus, it became reasonable for bankers and financial businessmen to watch for signals from the MOF and not market signals.

In the meantime, The Industrial Bank of Japan (IBJ) developed entrepreneurial capacities to screen the borrowers. Ueda (1993) considers this the beginning of the main bank system, a kind of coinsurance system in which banks delegate monitoring to a designated bank (the main bank of the borrowing firm).

The Japanese economy grew with alternating recessions and booms generated mainly by 
the "stop and go" policy of the Japanese government that was constrained by the balance of payments under the fixed exchange rate. In the late 1950s, the economy grew faster and the stock market advanced. In the late 1950s the motto of the security companies was, "Goodbye to the banks and welcome to the security companies." The government encouraged newly-introduced mutual funds and, in particular, public-bonds mutual funds that would facilitate the issue of bonds of public electric companies. Many customers also thronged around stock brokers in order to buy the newly-introduced mutual funds.

Starting in 1961, however, the stock market began to decline. The stock market index declined about 40\% from the peak of 1961 in July to the trough in July 1965. Difficulties developed in the security companies. Many clients demanded liquidation of mutual funds. Also they began to withdraw securities from the "broker managed" accounts, i.e., the accounts that were managed by security companies like deposits in the form of securities. In many cases, security companies had already sold the securities that were supposed to be in the account. In particular, the Yamaichi security company and the Oi security company were in deep trouble.

As difficulties developed, commercial banks started helping security companies by building the Nihon Kyodo Shoken (Japan Cooperative Securities), a holding company of stocks. Two hundred billion yen (at that time the exchange rate was $\$ 1=$ Y360) were provided as relief funds for the stock market. Security companies, which were afraid of the increased control by banks in the future, built another institution called Nihon Shoken Hoyu Kumiai (Japan Securities Holding Union) that engaged in price-supporting operations in the stock market. Banks like Fuji, Mitsubishi and JIB were trying hard to rescue Yamaichi and Oi.

The MOF had asked major newspaper and news agencies in Tokyo to refrain from leaking the news that there might be securities and financial difficulties. That the MOF exercised such influence may come as no surprise to a critic of Japan such as van Wolferen (1989). However, Nishi Nippon (The Western Japan Press), which was not a member of the major press club, leaked the news that Yamaichi Securities had serious financial difficulties. Customers who held management accounts in Yamaichi and other security companies started runs to withdraw from their accounts. The BOJ was reluctant to engage in an extensive relief operation.

On May 28, 1965, the Finance Minister Kakuei Tanaka, a very interesting but down-to- 
earth politician, ${ }^{5}$ met with the responsible central banker and commercial bankers. The meeting was with the Presidents of the Industrial Bank of Japan (IBJ), Fuji, and Mitsubishi, and the ViceGovernor of the BOJ. One commercial bank president said that they should proceed in a gradual, conservative way. Another suggested the closing of the security market for a few days in order to calm down public anxieties. According to the political scientist Kusano (1986, see also Goto, 1990), Tanaka, who favored forceful action instead, shouted, "Shut up! How can you be a responsible president of a large bank?" Kusano interprets this as a ritual to save the face of the BOJ Vice Governor. It was not any of the commercial banks, but rather the BOJ that had been reluctant. However, if the Finance Minister had scolded the BOJ Vice Governor, then it would have been a disgrace to the Central Bank and accordingly an embarrassment. Therefore, a commercial bank president took the blame as a scapegoat in place of the Vice Governor of the central bank. Consequently, the BOJ agreed to lend indirectly, about 5.3 billion yen to Oi Securities and about 28.2 billion yen to Yamaichi securities. Fortunately, the Japanese economy returned to a rapid growth path soon, and the loan was repaid in just four years.

This episode led to the MOF obtaining yet more power through the enactment of a licensing system. The approval of a license became mandatory for establishing a security company: ${ }^{6}$ licensing was intended as a safety measure aimed at preventing financial troubles like Yamichi's. Indeed, the licensing system passed the Diet on the same day that the bailout of Yamichi was politically decided.

\section{Bubbles and Crashes}

At the turn of the new decade of the 1990s, in January of the second year of the new Emperor's era, the "Heisei era," (marked by peace and success), the Tokyo stock market, which enjoyed a glorious record during the 1980s, started a precipitous decline. This decline was reminiscent of the financial crisis of the first episode that started in the second year of the Showa.

\footnotetext{
${ }^{5}$ Although only an elementary school graduate, Tanaka became the Prime Minister would later see his career end with the bribery charge that related to the Lockheed-All Nippon Airline (ANA) airbus procurement scandal.

${ }^{6}$ This system may be working as a good device for monitoring and controlling security companies; but it has recently been criticized by foreigners as yet another form of nontariff barrier.
} 
The Nikkei-Dow Index lost about $63 \%$ of its value in two and a half years. At the same time, soaring land prices ceased to appreciate and even started to decline substantially, almost for the first time in the postwar history.

Security brokerage firms struggled to recover from the loss of their public image that was caused by troubles with loss-offset practices; banks tried to reorganize their operations in the face of increased incidence of unsound loans. Commercial banks and other major financial institutions were subject to a more strict capital-asset requirement that was proposed by the Bank for International Settlements (BIS). For some of these institutions, the requirement became a substantial constraint for business. Mists of uncertainty prevailed for the future of the Japanese financial and security market. Some people even suspected that the declining stock market and failures of some financial institutions triggered chain reactions that undermined the systemic stability of Japan's financial market

There was a long period of excess liquidity and land and stock price booms during the late 1980s. From 1987 to 1989 , the BOJ kept its discount rate to a then historical low of $2.5 \%$ over a period of two years. Because of the appreciation of the yen, the price of the consumer price index and the wholesale price index were relatively stable. However, there were tremendous land price booms or bubbles; the total value of the land in Japan was estimated to be four times as much as the land value in the spacious U.S. The rapid growth of the stock market continued until the end of 1989. After Mr. Yasushi Mieno became governor of the BOJ at the end of 1989, he tightened monetary policy abruptly by raising the discount rate several times in order to recover the role of an independent and traditional Central Bank.

In the meantime, stock market "scandals" concerning loss-offset practices and cases of bad debts from banks, even from many respectable banks, erupted. Land prices showed substantial decline that was unprecedented in the land-scarce Japanese economy. The Nikkei Index that was almost approaching 39,000 yen in 1989 plunged to 15,000 yen. The BOJ and the government watched the situation, hoping in vain that the decline would be short lived, and that the decline of asset prices would be good medicine to cure the "bubble" psychology on land and stock prices.

In any case, the impact of disturbances on the financial sector was great. The number of bankruptcies exceeded six thousand in the first half of 1992. The magnitude of liabilities of 
bankrupt firms during Fiscal Year 1991(91/4-92/3) was 8,137 billion yen. It is estimated, in one of the most pessimistic scenarios (Kenji Uchida, Toyo Keizai, July 25, 1992), that the credit of about 68,000 billion yen held by banks may be unsound. The Japanese deposit insurance system charges only about $0.012 \%$ of the value of deposits and its standby credit line from the BOJ is only 0.5 billion yen. Thus, unless the BOJ acts as the lender of last resort, the Japanese financial system may well be threatened by a very uncertain future.

In August 1992, the government finally turned to an expansionary macroeconomic policy as an emergency relief measure. This time the government would rely on a fiscal expansion package. Amazingly, there was still some room for government expenditures in Japan because the Flow of Funds account showed a recent surplus in the I-S balance of the government sector that includes social security. The stock market temporarily rebounded with this fiscal package, considering it an encouraging signal for future economic activities, but the rebound was shortlived. The stock market still lingered within a low range owing to the uncertainty that was reinforced by the loss of leadership of the Liberal Democratic Party (LDP). ${ }^{7}$

There is a basic dilemma if one tries to prevent systemic instability of a financial system without impairing efficient intermediation of funds. To screen safe borrowers, to monitor them in economic activities, and to verify correctly the financial situation of a firm with delinquent loans, financial institutions should have positive and negative rewards corresponding to its economic success or failure. For that purpose, some intermediaries should be bankrupt. However, once a systemic failure of a national financial system develops, the government is often obliged to prevent bankruptcy of financial firms in order to stop the disaster of the total payment system.

Conceptually, the dilemma for the BOJ can be seen as the one for a two-stage game. Here one will easily detect the logic of time inconsistency. At the first stage of the game when financial activities are undertaken, participants are better motivated by the expectations of a cold-turkey government that does not rescue financial institutions. But, financial institutions

\footnotetext{
${ }^{7}$ One structural policy in the fiscal package was even amusing. The MOF asked for commercial banks to refrain from selling stocks. This request could not be really effective because it simply implied the postponement of supply and those unsold stocks could be a factor in being an excess supply for the future. This was typically Japanese, though, because this kind of moral suasion has been popular and was used by the Ministry of International Trade and Industry (MITI) as an emergency measure for declining industries like aluminum (See Dore, 1986).
} 
know that at the second stage when a crisis occurs, the government should rescue some of individual institutions in order to save the system. This is the dilemma between the ex-post rescues and ex-ante efficient incentive mechanism. This time inconsistency of the policy process makes it difficult to construct an "incentive compatible" financial system. The carrot and the stick should be used very skillfully. One needs here a "trembling hand equilibrium" defined by Selten. The BOJ should play the game as if it may be a cruel central bank instead of a benevolent one. It should leave in the mind of the public that in some cases the BOJ may not come to the rescue when a bank is bankrupt.

The Diet passed a series of laws on the rescue of financial institutions. They extended the bankruptcy clauses (the U.S. Chapters 7 and 13 equivalent) in the Bankruptcy Law to unincorporated financial institutions that had not previously been covered by the Bankruptcy Law. The National Deposit Insurance System was strengthened and the premium was increased. Notably, the government promised to compensate any loss in the principal of loans from the past for five years. This shows that Japan chose the way to emphasize the carrot rather than the stick. This policy choice certainly helps us avoid the systemic disorder from the present financial crisis, but it may prepare the hotbed for the next financial crisis by giving agents some assurance that government help will be in order in case of financial crises.

The Tokyo financial market has hardly shown any signs of recovery. Quite recently, the Yamaichi Securities Co. as well as the Hokkaido Takushoku Bank were declared bankrupt. The glorious record of Japan's growth in the last half of this century was thus tainted by financial turmoil.

Incidentally, the present financial crisis exposed the Achilles heel of the main bank system. According to the scheme, "the main bank" plays the principal role in screening a borrower, monitoring its managerial activities, and rescuing in case the borrower is in financial trouble. By playing this role collectively, banks can not only economize screening and monitoring costs without duplicating these activities, but can also engage in a kind of co-insurance. The bank that is designated to be the main bank performs the rescue operation because banks engage in a repeated game. If a bank defects from this role, sanctions will be applied later.

Even before this financial instability, there were cases of defection. In such a case, the 
main bank role was usually shifted to another bank from the bank that defected from the role of the main bank. In the present financial turmoil, many small financial institutions like "Jusen" (Special Residential Finance Company) could not stand independently. Nor could the main lenders endure the burden of debt. Finally, the government had to come to the rescue. At this point, Here the game was no longer the repeated game. This end game situation created difficulty for maintaining efficient allocation by the logic of the Folk Theorem. The co-insurance scheme could no longer function.

Even though Japanese financial institutions are under rather extensive administrative control, their openness to the public with respect to information was insufficient. Here again the practice tended to neglect the interest of depositors. As Fuchita (1997) emphasizes, while fewer regulations are necessary in most financial behavior, more regulations are necessary to make financial information more transparent. Otherwise, those who possess insider information will benefit substantially utilizing insider information. It is the task of Japan's leaders of the "Big Bang" to install necessary regulations to make information transparent to the public. Some information should be disseminated, but some should be blocked in order that the market mechanism works with less regulated financial behavior.

\section{The Incentive Problems with Administrative Control}

It is interesting to note the difference in actions taken in the two crises that hit Yamaichi approximately thirty years apart. In the first crisis leak ${ }^{8}$ in 1965, the Bank of Japan engaged in a rescue operation by the emergency lending of Y28.2 billion ( $\$ 78$ million). In the recent crisis in 1997, the government decided to let the company go bankrupt after the hidden loss of Y260 billion ( $\$ 2$ billion) was revealed.

In 1965, Japan was in a short recession in the middle of her rapid economic growth. Private bankers were willing and persuaded by the government to contribute to the rescue fund. The Japanese financial market was not under fierce international competition. The government had the leadership and accountability to rescue Yamaichi. In fact, the Ministry of Finance gained more power by establishing the system that requires approval rather than registration for opening

\footnotetext{
${ }^{8}$ The MOF was almost controlling the news media as well, but it was not perfect.
} 
a security company.

In 1997, Japan is in a long recession that had lasted seven years already. The Fuji Bank, the main bank of Yamaichi, is reported to have refused to help Yamaichi because of its own difficulties. The Japanese capital market is liberalized so much that the Japanese monetary policy cannot alone influence financial variables. The MOF has lost power as well as its credibility for reorganizing Japan's financial system in the failure.

The traditional system of government control of financial institutions were often called the "convoy" system. To protect the least efficient financial institutions, the MOF guided the financial industries to adjust the pace of its development so that the least efficient would survive. As the core of the convoy system, regulations prevalent in Japan can be classified into four categories (Yoshio Suzuki, 1997). The first category consists of the control on interest rates, fees and prices from financial services. The second is the restriction on jurisdiction and entry. The third is the restriction on the design of commodity. The fourth is to close the Japanese market from abroad. Particularly, the commodity design restriction is strange as well as stringent to the financial sectors that innovate by designing new commodities of financial institutions. Design of financial commodities was not possible without the approval of the MOF. Even at MITI's zenith of power, it did not regulate the design of automobiles.

A group of scholars maintain that the main characteristics of Japan's economic system in the post war period was developed during the preparation and the execution processes of World War II (Okazaki and Okuno eds., 1993). According to them, the economic system of Japan before the war was more or less like the Anglo-Saxon type of market system. The enforcement of the Foreign Exchange Control Law in 1933 was the first important step towards the controlled financial market. Also it was a proto-type of regulatory legislation that followed (Ueda, 1993).

The Ministry of Finance increased its control by the enactment of the Bank Law in 1927. The Ministry of Finance controlled entry, jurisdiction of business, deposit interest rates and opening of new branch offices. Perhaps with the assistance of the Bank of Japan as well as the Ministry of Finance, even loan rates and various fees were fixed by the associations of banks and other financial institutions.

Now, let us compare theoretically the incentive structures under the market principle with 
the incentive structure under government control. Under the market principle, banks are mainly concerned with market variables such as interest rates, exchange rates, amount of deposits, and profit rates. It is most important to predict the factors that affect those market variables. Financial innovations are contrived to beat the market. Under government control and administrative guidance, banks have to predict what government officials will do concerning the new financial instruments, how they will fix the deposit interest rate, and how the government will guide the exchange rate. Much unnecessary effort is spent on watching the government rather than watching the market. The existence of "the MOF liaison person" and "the Bank of Japan liaison person" in banks exemplifies this. The incentive structure is prone to lead to corruption, to inefficiency and to the lack of innovative activities. ${ }^{9}$

The incentive mechanism in Japan has worked only limitedly through price or interest rate signals. Under the existence of fixed interest rate differentials between deposit rates and loan rates, which were guaranteed by the convention supported by the MOF, profitability of banks depended primarily upon the quantity of deposits they could collect. The profit of a securities broker company depended on the amount of trade in which it could engage. The profit of an insurance company reflected the amount of contracts its marketing people, who were mainly parttime housewives, could collect. The profit of financial institutions was not much affected by the quality of services or prices such as interest rates, portfolio investment skills or the content of insurance contracts. To collect more deposits, trade more and write more insurance contracts, financial employees worked overtime with tremendous intensity indeed.

Under the system of administrative guidance, by coordinating with the help of the BOJ, the MOF put many regulations on interest rates, brokerage-transaction fees, dividend ratios, and the branch offices of these banks, securities companies and insurance companies (financial institutions hereafter). Moreover, the MOF controlled the kinds of financial instruments these banks, security companies, insurance companies could create and trade. Bankers, security brokers and insurance employees were at first obliged to engage in guessing games to guess what

\footnotetext{
${ }^{9}$ Of course, there are activities that are facilitated by watching what government will do. To decide which side of the road we drive, market process will take a long time and yield a lot of chaos. (One cannot wait until the evolutionary stable Nash outcome emerges.) Careful studies are still needed to see exactly what point the market signaling starts dominating the government signaling.
} 
the MOF intended to do with respect to these regulations before listening to the market signals. Since most of the regulatory measures took the form of "administrative guidance," and administrative guidance is almost by definition without legal ground, these measures have the nature of discrete decision rather than of rules.

Because of this highly regulated structure, Japan's financial institutions are constrained to a limited degree of freedom in business behavior. For example, if a credit union issued a saving deposit with a lottery attached, it met with strong resistance from the controlling agency as well as from other financial institutions. Because of the protective nature of these regulations, not only the regulating MOF but also the regulated financial institutions liked the regulation. It is always better for banks to have lower interest rates on deposits than on market demands, to have restricted entry of newcomers, and to have fixed fees for currency exchanges. It is always better for security companies to have fixed brokerage fees. Therefore, the regulation regime is an outcome of collusion between those who control and those who are controlled.

Against this profitable coalition, new entrants, in particular foreign entrants, had a strong disadvantage. Foreign financial firms certainly complained. The most important victims, however, were Japan's consumers. For a long time Japan's consumers suffered from the fixed interest rate policy and sacrificed themselves for the high growth path that the low interest rate had supported. Their only rewards were the stability of the financial system and the fruits from a high rate of growth. The latter reward ceased to come after the end of the high growth period (1950-73), and the first reward became uncertain after the outbreak of financial instability that began in 1990.

More precisely, the question of consumers' benefits should be considered in a dynamic context. By lowly fixed interest rates on deposits, and by the limitation of alternative saving assets by policy as well as the lack of information on comparative interest rates ${ }^{10}$, the Japanese consumers were deprived of being rewarded by the normal interest rate by international standards. Thus they were exploited in the short run. In the long run, however, they were rewarded for their

\footnotetext{
${ }^{10}$ For a long period, the advertisement involving the comparison of interest rates among financial institutions were "refrained" by the agreement by the Bankers' Association. The MOF at least allowed that practice, if not, enforced it.
} 
sacrifice at least partly by the fruits of a remarkable economic growth that might have facilitated the low interest policy.

For example, Dixit and Stiglitz (1983) have a model of monopolistic competition with increasing returns, which is extensively used in trade theory. The welfare implication of the model is that a country can improve its welfare by imposing a lump-sum tax on consumers and giving a subsidy for firms that enjoy increasing returns. I do not know for sure that the low interest policy was a proxy of a lump sum taxation. But, given the lack of alternative saving instruments, I may argue that the low interest policy played such a role. Thus, consumers must have retrieved a part of the results from their thrift in the long run.

To learn about the intention of bureaucrats is more important than to learn about future prices or economic variables. This violates the principle of efficiency because learning from bureaucratic signals seldom functions to improve national efficiency as well as learning how prices work on economic agents. This also violates the principle of equity because only insiders to the government circle can learn information for their future advantage. ${ }^{11}$

Incidentally, Feldman, Harada and Sakakibara, including government officials, defended the system as follows (Feldman, Harada and Sakakibara).

"Japan's financial markets remain quite distinct from those in Anglo-Saxon countries. Structural characteristics such as retail competition, effective syndication, long-term credit banks, and government financial institutions give the Japanese system some notable strengths that Anglo-Saxon counterparts lack. There is no reason whatsoever to change the basic institutions of Japanese financial markets. In a time of international tension and the increasing uncertainty, such institutions provide advantages to both Japanese corporations and consumers. It is an ingenious mechanism of pooling and diversifying risks at a national level."

It is curious that one of the authors, Eisuke Sakakibara, is considered to be one of the strongest proponents of the Big Bang. Even after the need for central coordination no longer existed, bureaucrats attempted, and succeeded, at least partly, to keep their control intact. Incumbent financial institutions in the regime wanted its continuation. And bureaucrats continued

\footnotetext{
${ }^{11}$ This reminds me of the recent story on financial firms that looked more to the group of Sokai-ya, literally gang members, often related to as Yakuza (the Japanese Mafia), who ask companies for money in exchange for securing the order of shareholders meetings. Neither is this an incentive compatible scheme.
} 
to govern by the logic of legal legitimacy not the nature of economic choice.

During the fast growth period, all seemed to have worked well. Japan was the largest source of supply of savings in the world economy. It suffices for Japan to continue her quantitative expansion. Now the quality of financial service is at stake. This urges the statesman to undertake the measures for deregulation.

A group of scholars maintains that the main characteristics of Japan's economic system in the postwar period were developed during the preparation and the execution of World War II (Okazaki and Okuno eds., 1993, Noguchi, 1995). Price freezes and government-guided mobilization of goods for war purpose remained as a basis of a controlled system by MITI after the war. The seniority wage system that is considered to be one of the three sacred treasures in the labor market was formed by the national wartime wage control. According to them, the economic system of Japan before the war was more or less like the Anglo-Saxon type of market system. The enforcement of the Foreign Exchange Control Law in 1933 was the first important step towards regulation in the financial market. Also it was a prototype of the regulatory legislation that followed (Ueda, 1993).

The wartime objectives before and during World War II were better served by government control than by market signals. This is called "the 1940" theory. It is worth examining. Coordination at the time of war certainly needed coordination through the center rather than through price signals.

\section{The Prospect of the Big Bang}

At present, the "Big Bang" is expected to proceed as follows. In 1998, the Foreign Exchange Law, precisely named "The Foreign Exchange and Trade Control Law," will be amended and the regime of essentially free capital transactions will be introduced. The word "Control" as a part of the name of the legislation is already an anachronism. It may be already too late that a country with a developed international capital market and a huge current account surplus finally joins the free international capital market. In any event, however, the process is finally taking the form of an international opening of the market and inevitable domestic deregulation. 
The process of breaking the wall of the Glass-Steagall type of regulation among different kinds of financial industries has been progressing. Banks are allowed to have subsidiaries that can engage in securities business, and so forth. However, in the future, the process of mutual entry will be accelerated by allowing holding companies in financial industries. Holding industries were limited because after the war, the American Occupation and Japan's succeeding governments worried about the resurrection of Zaibatsu through holding companies.

Let us sketch the process of "Big Bang". In April 1993, the Reform Act of Financial System (Kinyu Kaikaku Ho) became effective. The Glass Steagall type of restriction of mutual entries among sectors, notably between banking and securities, was relaxed, though several mutual entries became possible from banks to security businesses and vice-versa. More precisely, a subsidiary of a bank can start a security business and a subsidiary of a security firm can start a banking business. Though several restraints remain, this new law breaks down one of the barriers to entry among sectors. In the spring of 1997, the Foreign Exchange Act was amended and in April 1998, it will be put into force. Therefore, international barriers will be taken away and free movement of capital between Japan and abroad will result.

It is true that in the insurance industry as well, the new Insurance Industry Act (Shin Hoken-gyo Ho) became effective in April 1996. This law allows mutual entry from the life insurance sector to the casualty insurance sector, and vice-versa. As in the case of the Financial System Act, a subsidiary of a life insurance company can open a casualty insurance company and vice-versa. The pace of deregulation is slow, and will only be realized in 2001.

There have been many restrictions on entry and on the financial or instrument designs. Regulation on the design of financial instruments worked severely against efficiency in the financial market. In the securities business, the fee restrictions are being relaxed but only gradually. For example, in 1998, for more than $\$ 400$ million worth of transactions, the fees for securities' deals will be deregulated. But, for smaller transactions, fees are regulated and foreign security companies all have room to maneuver if they are permitted to compete.

In short, Japan is indeed planning to relax domestic regulations, but quite gradually. On the other hand, the pace of the opening of the market by the amendment is very fast. Thus, the following dilemmas will occur (Suzuki, 1997). If the high speed of opening is combined with the 
fast pace of activities of domestic regulation, then shocks to Japanese financial sectors will be large. However, if the government and BOJ are reluctant to advance domestic deregulation because of possible shocks, then a large part of the cream of financial business will be absorbed by foreign bankers and financiers, and a large amount of capital outflow will take place. The Tokyo market will be "hollowed" even more. As Suzuki argues, there is a trade off between efficiency and protection of incumbent Japanese financial business. If you want to protect the domestic financial sector, then most of the financial transactions will leave foreign markets. That is an expensive efficiency loss. On the other hand, if the government wishes to keep the efficiency and deregulate fast, then it will fit a certain group of financial institutions.

Thus, by 2001 even late comers like insurance companies will be deregulated and revitalized substantially. It is difficult to imagine that Japan will achieve these goals completely in 2001 for the following quantitative reasons. At present, Japanese households hold about 10 billion dollars in personal assets. Sixty percent of this money is held in the form of bank deposits or the postal savings deposits, $90 \%$ of which is held in fixed-principle asset policies. It is difficult to transform this pattern of financial intermediation to the market-oriented economy where the majority of assets in the portfolio is fluctuating. Eighty percent of bank assets, on the other hand, is invested in commercial loans to firms rather than in securities and bonds. Market instruments are relatively neglected. This will make the process of Japanese financial transformation rather difficult.

\section{Economics of the Unilateral Action}

First, let us consider the economics of unilateral actions in general. The process of unilateral action in a trade model consisting of commodity trade or with trade of services without any direct investments are as follows: Suppose there are three sectors in the economy - two regulated sectors where a unilateral action takes place and the third sector is the export sector of the country. Figure 1 illustrates a simple case of unilateral action. The aggregate production of financial services is depicted on the horizontal axis and the aggregate production of other goods is depicted on the vertical axis. A unilateral action has a domestic as well as an international effect. The domestic effect comes from the increased mobility of resources between sectors and usually 
expands the production possibility locus. The Figure illustrates a special case of a rectangular production opportunity. There the supply of the financial sector's output increases from $\mathrm{P}$ to $\mathrm{Q}$. The international effect is the worsening of the terms of trade. Only if this effect is stronger than the domestic gain, as in the case of immiserizing growth (Bhagwati, 1958), then the national welfare will deteriorate.

If a country is small, it will not change the terms of trade. A unilateral action in a small country will thus certainly improve the national welfare, as indicated by $\mathrm{C}_{0}$ (we assume trade restriction at the beginning) to $\mathrm{C}_{1}$ in Figure 1 where by the "small country" assumption the terms of trade remain the same as the dotted line. A unilateral action in a large country, where it can create the terms of trade advantage by trade restriction as with tariffs and quotas, then the unilateral action may work against national welfare because of the loss due to the worsened terms of trade. If the terms of trade worsen as depicted by the solid line in Figure 1, the equilibrium shifts from $\mathrm{C}_{0}$ to $\mathrm{C}_{2}$. The tariff rate, or effective tariff rate corresponding to the quota, is lower than the optimal tariff rate for a country. Then, reduction of an outside tariff will deteriorate the welfare.

A unilateral action is often discussed in a group of countries. Suppose there are three countries. Two of them are in a closer group and they reduce the tariff rates on their traded goods for each other. The trade creation effect helps the participants. If there is a third country, the unilateral action will imply the reduction of the tariff of the third country as well. To repeat, one effect is the effect of liberalizing tariffs within the zone, and the other effect is opening a zone to a third party.

So far, we have abstracted from foreign direct investment (FDI). Unilateral liberalization of the service industry by industrializing the FDI can be analyzed in the same way. FDI shifts up the production frontier, and as long as the required rate of return to foreign investor does not increase substantially, the unilateral action is always profitable. As long as the domestic economy is sufficiently open, there is no room for the Brecher-Diaz Aljanderos (1977) Uzawa (1969) effect to work. Accordingly, FDIs will benefit the national economy in general.

There is an analogy to unilateral action like the "Big Bang" in Japan from the above story. If you liberalize among three major financial sectors, banking, securities and insurance, and 
between subsectors like casualty and life insurance, then the unilateral action will increase the supply of services produced by domestic industry. This is a definite gain. The terms of trade of the services however, may worsen and offset the effect of integration by lifting regulations on domestic sectors and resulting in more competition in domestic sectors. The unilateral action will benefit the Japanese economy, unless the liberalization of the financial market to foreign entrants increases the price of financial services and leads to the increase in foreign financial firms' profits to such an extent that the effect of the upward sloping supply curve of the financial service offsets the domestic gain in financial service production. Foreign investors cannot benefit from the protected price of services because the unilateral action implies that the domestic market is deregulated. Unless the loss from terms of trade is large enough to immiserize the country, the Japanese economy as a whole will gain. If the political process, due to sectoral interests, does not prevent the "Big Bang," there is a national incentive to create it.

In spite of the positive economic benefits for the nation, in the past neither the MOF, nor the BOJ, nor bankers were willing to open the Japanese economy. The reason is, of course, that we have neglected the political process aspect of financial deregulation. It is not a nation as a whole, but each interest group that has a reservation welfare (utility) level in order to be induced to participate in a reform. Crisis deteriorates the welfare at status quo, the reservation utility level. Now the Japanese economy is in trouble and financial sectors are in serious trouble. Japan can afford to adopt drastic measures to get out of this impasse. For example, there are signs of the decline of Japan's role in the world market. During 1989-1995, New York's market increased its share from $43 \%$ to $52 \%$ in foreign exchange transactions. London's share went from $30 \%$ to $29 \%$. In the meantime, Tokyo lost its weight from $27 \%$ to $19 \%$. In the volume of transactions, during the ten years 1985-1995, New York kept its share from 64\% to 60\% and London increased its share from $6 \%$ to $23 \%$, Tokyo lost its weight from $30 \%$ to $17 \%$.

This loss of transaction volume was triggered by the action of the Japanese government. In response to scandals related to derivatives, the MOF raised for a while the margin requirement and other fees in the Osaka exchange. The policy backfired and the MOF had to reverse it. Anyway, now Japan is in such deep financial trouble and any lifeboat is welcome in this situation -- as a Japanese proverb says, "A drowning man will grab at even a straw." Many vested interests 
in financial sectors or bureaucracies are no longer strong obstacles. Participants now understand the need for reform of the Japanese financial system.

\section{The Political Economy of the "Big Bang"}

The first question that comes to mind concerning the political economy of Japan's "Big Bang" is: Is it real? Japanese financial sectors and the Japanese government had a long history of resistance to pressures from abroad to open the Japanese market. During the early 1980s, the U.S. Congress and the U.S Administration tried to open the Japanese market in order to arrest the excessive overvaluation of the yen before the Plaza Accord. There was a joint group called the Yen-Dollar Ad-Hoc Committee. However, as Frances Rosenbluth (1990) vividly describes in her

report to the Joint Economic Committee of the U.S. Congress, Japan's Minister of Finance did not wish to open the domestic market and to lose the authority to regulate it, and the Bank of Japan hesitated to open the Japanese market fearing loss of control of the money supply. Those efforts on the part of the U.S. had limited success.

Therefore, an interesting question is: Why now? Japan is taking the initiative in this unilateral action. One skeptical view is that Japan is neither serious about opening the domestic financial market nor prepared to deregulate the financial market substantially. They are using the "Big Bang" as an excuse for the slow process of deregulation or as a means of distracting people's attention from the difficulties of the financial market and the failure of monetary policies. I do not, at least for the moment, adopt this skeptical view, and proceed to the question: What can we normally expect if the government's intention is to trigger a serious "Big Bang"?

Probably until the recent period, Japan's government or the MOF, had the interest to protect the ancient regime against foreign pressure. Now after the great financial collapse of the system, the government might have changed the assessment of protection of Japan's financial industries. With the older system, sufficient incentives can no longer be secured. With the Big Bang the government we can expect the emergence of a sound market mechanism in the financial market. Also, it can divert the people's attention from the waste and corruption of the older system to the forward-looking vision of a financial market open to the world.

Then, how can this deregulation due to the Big Bang vitalize the Japanese financial market 
and succeed to foster financial entrepreneurship in Tokyo? I am rather optimistic because human capital able to effect sophisticated financial activities abounds in Japan. The elimination of incentive restraints that originated in the 1940 system will help the revitalization of Japan's financial market that has enormous strength in terms of the amount of savings it generates.

Here let us reflect the basic mechanism of institutional reform. Institutional reform does not realize if participants agree to adopt a new rule or, at least, are reluctantly persuaded or forced to follow a new rule. In this weak sense, the "individual rationality" requirement is necessary. In theoretical writing "individual rationality" implies that the new plan satisfies individuals to keep their reservation utility level. In international negotiations, nations are motivated to agree with a new plan if it improves or at least sustains the welfare level of interest groups. Thus, "group rationality" is desired. In other words, every group has to be convinced and the welfare of the group will not deteriorate. It is, of course, difficult to satisfy completely this condition for groups with different interests. Thus, domestic impasses create obstacles for international negotiations. In practice, it is difficult to satisfy all the interest groups. The idea of "win-set" in a two-level game (Putnam, 1988) implies that the negotiation is conducted on the set in the bargaining box where the outcome will not jeopardize the re-election of the incumbent party. By the Ulysees and Sirens effect, the government bound by domestic restrictions may find more bargaining power in international negotiations (Putnam, 1988). In some case, however, strongly bound governments may not be able to reach an agreement.

Consumers have been neglected for a long time in the Japanese financial intermediation process. Interest rates on deposits were often below the rate of inflation in CPI. The control of the MOF on the financial industries, that is, banking, securities, and insurance industry have been very tight. However, since those financial industries have been benefited by many patterns of control such as restriction of entry and the fixing of interest rates and fees to levels that are favorable to the them, financial institutions also enjoyed this lucrative state. Politicians obtained contributions from interest groups like financial institutions, and they influenced the bureaucracy. Rosenbluth (1989) is right in recognizing the power of politicians in determining the balance of interests among the financial institutions, that is, bankers, stockbrokers and insurance business. To me, however, it is spurious to ask who controls whom, or who influences whom. Economic 
agents in the financial industries, bureaucrats, and politicians seem to have been enjoying a salonlike coalition. Only the consumers are out of this coalition.

As already discussed, the economic process can be regarded as a two-stage game, which consists of the game to agree on a set of rules, and the game of economic behavior given a chosen set of rules. ${ }^{12} 13$ It is not easy, however, for participants, to agree on a set of rules. Evolutionary game theory emphasizes natural selection. A viable or efficient rule will be chosen by a repeated process of survival of adaptable participants. This seems to be a too long-run view to be applied to economic organization.

Once a big dislocation of the environment takes place, then more likely the present status quo turns unsatisfactory. For the Japanese financial industries, the present rule is no longer something to defend. The present crisis will make it easier for groups to agree on a new rule. As Samuelson (1967, p. 699) puts it, "One does not have to be cynical, but merely realistic to guess that if fundamental changes are to come, they will come in the wake of some international crises rather than as a result of predetermined planning and agreement."

In an impasse, political leadership plays a role. Many groups may be reluctant to join the reform. But, provided that a new rule is potentially improving, side payments can be made by those who gain from the new rule to those who lose. And, the side payments can be facilitated by the leadership of politicians. As Frohlich, Oppenheimer and Young (1971) convincingly argue, politicians put inputs in terms of effort, persuasion and funds to realize political benefits that they called "leadership surplus," like the "producers' surplus." Also, the attempt to change the perception or the images of people of the new rule is crucially important (Haas, 1992).

Thus, political entrepreneurship will understand the pay-off structure for the participants, change the perception of the pay-off structure to other participants, spend his (her) resources to collect leadership surplus later, make necessary side payments to make the new system satisfy the

\footnotetext{
12 Take for a moment, the example of international finance, the choice of the international monetary regime. Monetary policies interact when a monetary regime is chosen to be a fixed exchange rate system or a flexible exchange rate system. The first stage was governed by the expectation of what happens if a certain regime is chosen. The subgame perfectness is usually required.

${ }^{13}$ Nakasone's leadership, with economist Kato's help, enabled the most successful privatization, that is, the dissolution of the National Railway (NR) to Japan Railways (JRs).
} 
reservation utility constraint, and use his (unlikely "her" in Japan) power as a threat to non conformism. Thus, the political leadership can work as a catalyst to shorten the time by which evolutionary solutions are chosen by natural selection. The fact that finally this liberalization and deregulation are likely to be realized depends strongly on the strong leadership of Ryutaro Hashimoto.

Looking at the situation a little more carefully, one can find that the first stage of the choice of regimes can be approximately regarded as a one shot game or a once and for all game. Countries decide whether or not to join a regime. If countries of sufficient numbers and countries that have sufficient relative mass in the world agree, then a new regime is adopted. Once a certain rule is adopted, countries develop expectations on others' behavior, and the repeated play will continue. When a strong shock hits the system, the ongoing rule may turn out to be nonviable, and again a new rule may be adopted.

Incidentally, the role of the Postal Saving System (PSS) needs some explanation. This time, the Japanese government imitated the British Postal Saving System, and, surpassing its originator, has created a gigantic financial intermediary, probably the largest financial intermediary in the world. Banks are criticizing this large rival institution. They say that the PSS is highly subsidized by the consolidated account with the post and telecommunication activities of the System, that the System does not follow the market principle, and that this non-private institution will be an obstacle to the Big Bang. The PSS, or the Ministry of Post and Telecommunication, argues, on the other hand, that banks are colluding in giving the depositors low rates of interest through the protection of the MOF.

Basically, this is a tug of war, or a zero sum game, between banks and the PSS. The following remarks are in order:

(1) Because of the economies of scope that deposits are collected by the post offices that engage in mailing activities, and because of the low labor and building cost of the PSS, the cost of fund collection is often less expensive in the PSS. This advantage of fund absorption of the PSS should be utilized.

(2) On the other hand, the PSS does not have sufficient skills and entrepreneurship for managing this huge pool of funds. In fact, the use of the fund was managed by the "Fund 
Managing Account" of the MOF. This fund supply was a major source of the Fiscal Investment Loan Program (FILP) and an effective measure of conducting the industrial policy. Now the need for the industry specific supporting policy became less important.

\section{Concluding Remarks}

The huge surplus of savings by Japan was good for the world and a major source of the strength in Japan's financial business. By the mere amount of her savings, Japan can assume a monopolistic position in international finance. Any reference by a Minister to the possibility, if not the intention, of Japan to withdraw money from the initial bid for the newly issued U.S. treasury bills could cause a turbulence in the U.S. bond market as well as the currency exchange market.

Recent incidents that cast doubt on the health of Japan's sector suggest that this quantitative dominance was not necessarily accompanied by the quality of financial services nor by the efficient financial market and organizations. Also, the huge financial flows from Japan were facilitated by consumers and depositors that endured substantially lower interest rates and lower quality of financial services for a long time. From the standpoint of consumers, who provided savings, they were hardly rewarded. Now Japan has to earn income by her human skills and not merely by its massive savings.

We have argued that "Big Bang" can be regarded as a unilateral action, and that economic rationales exist for Japan to proceed to this unilateral action. Also the present turmoil in Japan's financial market may mitigate the political-economic resistance to a reform of the system.

The "Big Bang" proposal serves to distract the public attention from the present difficulty, to coordinate people's expectations to a somewhat rosy picture in the future, and to create a new image of a deregulated world. These intentions are welcome. We may watch whether this meaningful attempt of a unilateral opening of Japan's financial market will actually be realized despite the existence of potential resistance by vested interest groups in Japan's financial circle.

The "Big Bang" is an attempt to revive Japan's financial world. It is also a typical example of a unilateral action for liberalization. If it succeeds, then it will help Japan's economy to realize 
an economy that effectively uses its large savings. The Japanese "Big Bang" as a Unilateral Action may work as a panacea. 


\section{BIBLIOGRAPHY}

Bhagwati, J., 1958, "Immiserizing Growth: A Geometrical Note," Review of Economic Studies, 25 (June) pp. 201-205.

Big Bang, Shu-kan Toyo Keizai, March 1, 1997.

Brecher, R. A. and C. F. Diaz Alejandro, 1977, "Tariffs, Foreign Capital and Immerising Growth,” Journal of International Economics, Chapter 23.

Dixit and Stiglitz, 1983, "Monopolistic Competition and Optimal Product Variety," American Economic Review.

Dore, R., 1986, “Government and Business Enterprise,” Flexible Rigidities, Stanford University Press.

Feldman, R., Y. Harada, and E. Sakikibara, 1980, Report to the Joint Committee, U.S. Congress.

Frohlich, N., J. A. Oppenheimer, and O. R. Young, 1971, Political Leadership and Collective Goods, Princeton University Press.

Fuchita, 1997, Shoken Biggu Ban (The Security Industry with Big Bang), Tokyo: Nihon Keizai.

Goto, S., 1990, Showa Kinyu-shi (Financial History of Showa) Jijitsushin-sha.

Haas, P., 1992, "Introduction: Epistemic Communities and International Policy Coordination," International Organization, 46, No. 1 (Winter), pp. 1-35.

Hamada, K., 1994, "Japan's Prospective Role in the International Monetary Regime," in Japan A New Kind of Superpower?, C. Garby and M. Brown Bullock, eds., Woodrow Wilson Center Press, pp. 143-158.

Hamada, K., 1993, "Bubbles, Bursts and Bail-outs: Comparison of Three Episodes of Financial Crises in Japan," February 1993, presented at the National Taiwan University (National Science Council Lectureship Program) March, 1993. Forthcoming in Japan's Economy after the Miracle (tentative title), McQuarie University conference collection volume, by the Macmillan Press of London.

Imai, K., 1997, Nihon ban Biggu Ban (The Big Bang in the Japanese Style), Toyo Keizai.

Iwamura, T., 1995, Ginko Keiei no Keiei Kakushin (Innovations in the Bank Management), Tokyo: Toyo Keizai.

Japan's Economic Challenge, 1990, Joint Economic Committee, October. 
Kusano, A., 1986, Showa 40-nen 5-gatsu 28-nichi Yamaichi Jiken to Nichigin Tokuyu, (The Yamaichi Incident and the Bank of Japan Relief Loans) Nihonkeizai Shinbun.

Morishima, M., 1984, Why Has Japan Succeeded?, Tuokyuo: TBS Buritanika.

Nikkei Shimbun, ed., 1997, Do naru Kinyu Biggu Ban (What happens in the Financial Big Bang?), Tokyo.

Noguchi, Y., 1995, 1940-nen taisei: saraba "senji keizai" (The 1940 Regime: Good Bye to the "War-Time Economy”) Tokyo: Tokyo Keizai Shinposha.

Ogata, K., 1996, En to Nichigin (The Yen and the Bank of Japan), Chuokoron, Tokyo.

Okazaki and Okuno, eds., 1993, Gendai Nihon Keizai Sisutemu no Genryu (The Origin of the Modern Japanese Economic System) Nihon Keisai Shinbum 1993.

Putnam, R. D., 1988, "Diplomacy and Domestic Politics: The Logic of Two-Level Games," International Organization 42 (Summer) pp. 427-460.

Rosenbluth, F., 1989, Financial Politics in Contemporary Japan, Cornell University Press.

Rosenbluth, F., 1990, Foreign Pressures and Liberalization of Japan's Financial Market: Japan's Economic Challenge, Joint Economic Committee, October 1990.

Samuelson, P. A., 1967, Economics: An Introductory Analysis, McGraw-Hill.

Suzuki, H., 1997, Biggu Ban No Jiremma (The Dilemma of Big Bang) Tokyo: Toyo Keizai.

Tokyo Stock Exchange, 1928, The Fifty Years History of Tokyo Stock Exchange, Tokyo.

Twanara, T., 1995, Ginko No Keiei Kakashin (Managerial Innovations in Banking), Tokyo: Toyo Keizai.

Uzawa, H., 1969, "Shihon Jiyuka to Kokumin Keizai (Liberalization of Foreign Investments and the National Economy)" Ekonomisuto 23 (December), pp. 105-122.

Van Wolferen, K., 1989, The Enigma of Japanese Power, Knopfs.

Yasuyuki Fuchita, 1996, Shoken Biggu Ban (The Big Bang in the Security Market), Toyo Keizai: Tokyo. 


\section{FIGURE 1}

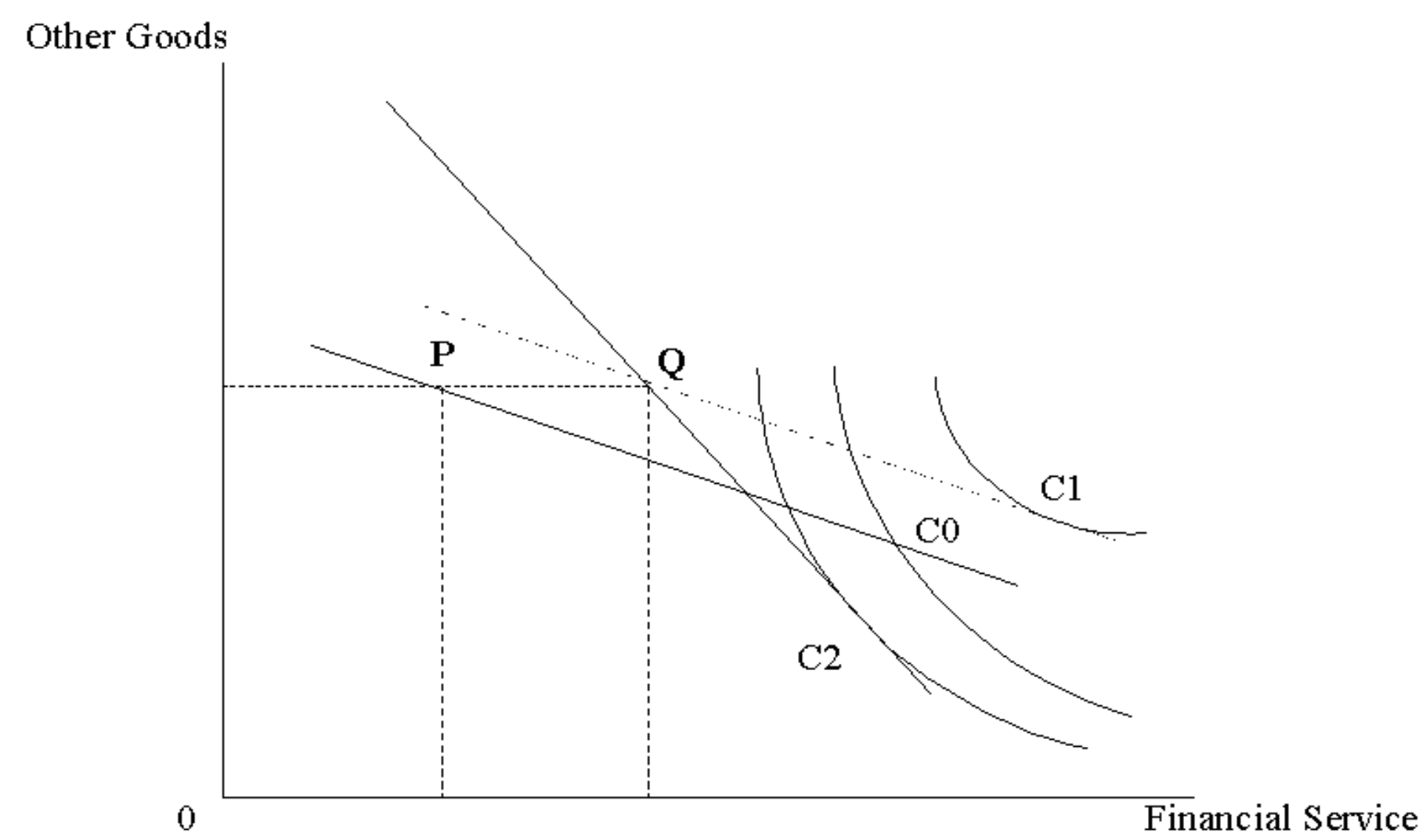

